\title{
Implications of COVID-19 Lockdown on South African Business Sector
}

\author{
Chuks I Ede ${ }^{1}$, Mfundo Mandla Masuku² \& Nokukhanya $\mathrm{N} \mathrm{Jili}^{1}$ \\ ${ }^{1}$ Department of Public Administration, Faculty of Commerce, Administration and Law, University of Zululand, \\ South Africa \\ ${ }^{2}$ School of Development Studies, Faculty of Economics, Development and Business Sciences, University of \\ Mpumalanga, South Africa \\ Correspondence: Mfundo Mandla Masuku, School of Development Studies, Faculty of Economics, Development \\ and Business Sciences, University of Mpumalanga, South Africa.
}

Received: November 19, 2020

Accepted: December 30, 2020

Online Published: March 18, 2021

doi:10.5430/ijfr.v12n4p12

URL: https://doi.org/10.5430/ijfr.v12n4p12

\begin{abstract}
The COVID-19 pandemic in South Africa spelt untold adversity on many businesses in the country. This is attributable to the precautionary measures implemented by the South African government to contain the ferocious disease spread across various levels in the society. This article examined the many implications of the pandemic on the business sector in South Africa through the period just before June 2020. The article adopted a qualitative approach to critically examine the implications of the COVID-19 pandemic on the business sector in South Africa. It utilised Statistics South Africa's reports and contemporary literature on the effects of COVID-19 on the business sector which was used as a source of reference. The statistical evidence is based on experimental data for May 2020, as derived from over a thousand registered businesses operating within the formal sector from various industrial groupings in South Africa. The period under review is remarkable because the business's effect of the pandemic became visibly alarming while the lockdown phases were reduced from Level 5 to Level 4 within the period. The private sector of the economy, known for its huge economic sustenance of most of the country's labour force, was already at the firing line as all 'nonessential' businesses succumb to government's strict regulations on socioeconomic activities during the phased lockdowns. The hitherto struggling economy, barely sustained by this sector, eventually caved in with over half of its gross domestic product, shrinking attributable to the unparalleled adverse effects that attended the dreaded pandemic. Although government is still battling with the nation's economic recovery process, many businesses counted their losses from the first few months of the lockdown, as portrayed by plentiful evidence from the national statistical body.
\end{abstract}

Keywords: South Africa, COVID-19, government, business sector, economy

\section{Introduction}

The coronavirus pandemic brought economic hardships for the South African and global populace in developing countries. Reports from South Africa's national statistical body, Stats SA (2020a) indicate that as early as April 2020, businesses under the private sector's formal division reeled from the pandemic, as the national lockdown was fully implemented. The phased lockdown approach reiterated at the middle of the month by President Cyril Ramaphosa as in full operation at alert Level 5 but was later reduced to Level 4 through May and subsequently to Level 3 by June and July. Besides the tremendous concern on health and safety for the citizenry during each phase, the pandemic lockdown implies that certain socioeconomic activities were prohibited - or came under strict government regulations. Most of the social, especially economic activities, remain banned or partially allowed during lockdown alert Level 4 . The losses that trail the initial levels are already quantifiable and easily deducible - records are indispensable in enabling an in-depth understanding of the scale of effect from the coronavirus on the formal business sector. With such cognisance, therefore, the government can gain adequate foresight as the custodian of the economy on rescue efforts required for the recovery of the formal business sector, and how best its strategies can be effectively optimised. The affected businesses and sector, conversely, may discern the magnitude of COVID-19 lockdown's effect on their operations, and reckon their recovery rates and operational progressions about their modus operandi before, during and after the pandemic. 
Kanu (2020) and de Villiers et al. (2020) contend that many distraught Third World countries still suffer severe economic decline through loss of jobs, falling per capita income and unsustainable debt trends resulting in exacerbating poverty. In the South African context, most workers lost their jobs while many are working on reduced rosters. de Villiers et al. (2020) complains about South Africa's unemployment rate, which was $29 \%$ in December 2019, placing the country 4th highest in the world. This situation suggests that the government needs to keep taxes low, ensure that food prices do not skyrocket unreasonably, and balance the demands of workers for a salary increase with the reconstruction of the business sector (Bono, 2020). A qualitative approach was employed to critically appraise the literature on the implications of COVID-19 in the South African business sector. It involves literature review and reports from global and national organisations, focusing on the COVID-19 lockdown influence and regulations on the business sector.

This article, therefore, follows a content analysis in identifying, classifying, and interpreting dynamics of COVID-19 in the South African context. The statistical evidence is based on experimental data for May, as derived from over a thousand registered businesses operating within the formal sector from various industrial groupings in South Africa. The report employed a qualitative approach by reviewing the literature to examine the implications of COVID-19 on the South African business sector. The authors used search words, such as 'COVID-19' and business sector in South Africa or economic implications during the pandemic in developing countries.

The academic articles, global organisations and South African COVID-19 statistics reports were purposively selected from 2012 to 2020 to have a deeper understanding of factors influencing the business sector during the pandemic. The literature was extracted from research databases, including Emerald Insight Journals, Sabinet and google scholar. All the selected sources were screened by title, abstract and full text using the inclusion and exclusion criterion of the year of publican 2012 to 2020 and the recent literature on the COVID-19 pandemic. These secondary sources were regarded as highly beneficial in studying a contemporary phenomenon with a wide geographical scope. With the emergence of the pandemic, it became important to analyse how COVID-19 harmed the country's economy.

\section{An Overview of the COVID-19 Pandemic Situation in South Africa}

South Africa's rapid upsurge of the coronavirus pandemic was among the fastest in the world since 5 March 2020 when the National Institute for Communicable Diseases (NICD) reported the first COVID-19 case (NICD, 2020). The period under review is of utmost significance since the affected businesses in their various industrial classifications by the government (Table 1), aptly responded to the commission's affect surveys concerning the formal business sector and COVID-19 pandemic. These were the third of the fortnightly surveys that earlier began on 30 March 2020. This report combined the survey that spanned the whole of May comprise findings on "the effect of the pandemic on South African business at Level 4 lockdown" (Stats SA, 2020a:1).

Table 1. Industrial classifications of listed businesses under survey

\begin{tabular}{lll}
\hline Industry & Number of businesses & \% of total \\
\hline $\begin{array}{l}\text { Agriculture, hunting, forestry } \\
\text { fishing }\end{array}$ & 177 & 16.4 \\
\hline Mining \& quarrying & 27 & 2.5 \\
\hline Manufacturing & 226 & 20.9 \\
\hline Electricity, gas \& water supply & 14 & 1.3 \\
\hline Construction & 61 & 5.7 \\
\hline Trade & 185 & 17.1 \\
\hline Transport, storage \& communication & 106 & 9.8 \\
\hline Real estate \& other business services & 126 & 11.7 \\
\hline Community, social \& personal & 116 & 10.8 \\
services & & 41 \\
\hline Other & $\mathbf{1 0 7 9}$ & 3.8 \\
\hline Total & & $\mathbf{1 0 0 . 0}$ \\
\hline
\end{tabular}

Source: Stats SA (2020a) 
The latest situation reports by the World Health Organisation (WHO) (2020) reveal that Africa's COVID-19 cumulative cases of 1094 per a million of its population are still spearheaded by South Africa with over 11600 transmission rates in every 1000000 individuals in the country. This means that the continent's positive cases of COVID-19 are more than halved by just one of its 54 countries, which regrettably doubles this seedy role with the most cumulative casualties (Figure 1). The implications of this sordid trend on the nation's economy and the people are far worse inscribed, but better imagined. Of its massively progressive and highly diversified economy on the continent in recent times (Swilling et al., 2016:53,414), South Africa's private business sector has borne most of the brunt of the pandemic due to government's umpteenth restrictions on normal economic activities in the sector (Ramaphosa, 2020).

\begin{tabular}{|c|c|c|c|c|c|c|c|}
\hline Reporting Country/Territory/Area & $\begin{array}{l}\text { New cases in } \\
\text { last } 7 \text { days }\end{array}$ & \begin{tabular}{|l} 
Cumulative \\
cases
\end{tabular} & \begin{tabular}{|l|} 
Cumulative \\
casesper1 \\
millon \\
population
\end{tabular} & \begin{tabular}{|l|} 
New deaths \\
in last 7 \\
days
\end{tabular} & $\begin{array}{l}\text { Cumulative } \\
\text { deaths: }\end{array}$ & $\begin{array}{l}\text { Cumulative } \\
\text { deaths per } 1 \\
\text { million } 1 \\
\text { population }\end{array}$ & Transmission classification \\
\hline Africa & 29169 & 1227719 & 1094 & 991 & 27255 & 24 & \\
\hline South Africa & 11180 & 690896 & 11649 & 735 & 17673 & 298 & Community transmission \\
\hline Ethiopia & 6441 & 83429 & 726 & 70 & 1277 & 11 & Communitytransmission \\
\hline Kenya & 2235 & 41158 & 765 & 35 & 760 & 14 & Communitytransmission \\
\hline Uganda & 1047 & 9538 & 209 & 7 & 86 & 2 & Communitytransmission \\
\hline Algeria & 945 & 52940 & 1207 & 39 & 1795 & 41 & Communitytransmission \\
\hline Angola & 876 & 6246 & 190 & 29 & 218 & 7 & Communitytransmission \\
\hline Nigeria & 816 & 60103 & 292 & 2 & 1115 & 5 & Communitytransmission \\
\hline Mozambique & 795 & 9844 & 315 & 6 & 70 & 2 & Communitytransmission \\
\hline Caboverde & 617 & 6913 & 12434 & 12 & 74 & 133 & Communitytransmission \\
\hline Zambia & 585 & 15415 & 839 & 3 & 336 & 18 & Community transmission \\
\hline
\end{tabular}

Figure 1. Weekly epidemiological and operational updates of countries in Africa, 11 October 2020 Source: WHO COVID-19 Situation Report

Despite indescribable carnage with losing many lives from the pandemic, there was an unapparelled scale of losses in livelihoods, as "real gross domestic product (measured by production) decreased by a record $51,0 \%$ in the second quarter of 2020 owing to the effect of the COVID-19 lockdown restrictions" (Stats SA, 2020b:2). For instance, from the 29169 COVID deaths witnessed in Africa since the pandemic, 11180 were reported in South Africa amidst national cumulative cases of 690896 for 1227719 in the continent (Figure 1). This implies that more than half of both the COVID cases and casualties are recorded in South Africa.

\section{South Africa's Formal Business Sector Before the COVID-19 Pandemic}

The South African economy experienced significant changes since 1994 regarding certain indicators like economic growth, real income per capita, net global capital flows, average Consumer Price Index (CPI) inflation, and its gross fixed capital formation (Roux, 2016). These changes amount to appreciable heights (compared to the defunct Apartheid regime), despite existing socioeconomic challenges that bequeath each successive democratic administration in the country. Like most African countries, South Africa's economic success is derived from its numerous natural resources which range from solid to nonsolid minerals (Bakari, 2017:2). But unlike many nations in the continent, the country has sustained a fairly diversified economy, with services accounting to almost $70 \%$ of total economic activity. This has resulted in rapid economic growth that qualifies the country as an upper-middle-income economy, with [an investment base] larger than that of all but 27 other countries in the world (Roux, 2016). Besides the recent pandemic-induced economic recession which now shrank the country's economic capacity by half, historical evidence from Stats SA indicates that South Africa has "experienced eight recessions since 1961", with "the longest [running] over two years: 1991 and 1992" while others occurred at 1974/5, 1976/7, 1982/3, 1985, 1990, 2008/9 and 2016/17 (Stats SA, 2020c).

The private business sector was accredited as the major driver of South Africa's economy courtesy of thriving small and medium-scale enterprises. According to McKinsey and Co. (2020:3), these SMEs "represent over 98\% of businesses" in South Africa with an employment generation capacity that ranges "between $50 \%$ and $60 \%$ of the country's workforce across all sectors". Through radical economic policies like Incubation Support Programme (ISP) and Black Business Supplier Development Programme (BBSDP) with the National Youth Development Agency (NYDA) (Ede 2017:51) targeting on most African populace before disenfranchised during the previous regime, small and medium-scale enterprises (SMMEs) have gained prominence as "arguably the most dynamic sector of the economy" (Smulders et al., 2012:211). So, it was almost predictable that the "ongoing COVID-19 pandemic ... 
causing untold human suffering ... is likely to leave an indelible effect on ... small and medium-sized enterprises (SMEs)" in the country, as it does at continental sphere (McKinsey \& Co. 2020:2).

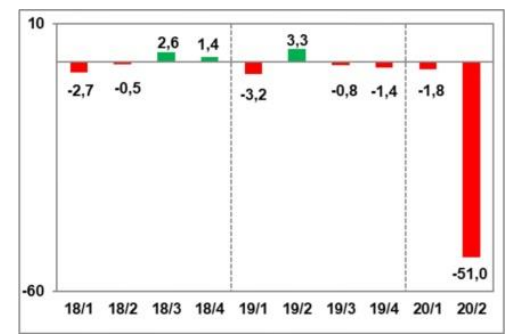

Figure 2. The situational hindsight of the South African economy January 2018 till June 2020

Source: Stats SA (2020b:2a)

Having pulled through turbulent times before now, leading to its consecutive downgrades and insignificant ratings over the past two to three years (Figure 2), the South African economy was barely careering before the pandemic that now leaves it almost grounded. The effects are evident with measurable downturns of $-2.7 \%$ and $-0.5 \%$ in $1^{\text {st }}$ and $2^{\text {nd }}$ Quarters of $2018,-3.2 \%,-0.8 \%$ and $-1.4 \%$ in $1^{\text {st }}, 3^{\text {rd }}$ and $4^{\text {th }}$ Quarters of 2019 , with a historic contraction of $-51.0 \%$ within the second quarter of 2020 after initial slum of $-1.8 \%$ in the $1^{\text {st }}$ Quarter. There were, however, measurable growths as witnessed within the $3^{\text {rd }}$ and $4^{\text {th }}$ Quarters of 2018 (2.6\% and $1.4 \%$ respectively) and $2^{\text {nd }}$ Quarter of 2019 (3.3\%). Regrettably, the reality of the adverse effects of the lockdown - earlier conceived as a precautionary measure - eventually left most SMEs at the formal sector even more grounded.

\section{Adverse Consequences of COVID-19 Lockdown on South African Formal Business Sector}

It is noteworthy that most businesses in South Africa operate in both the formal and informal (sub) sectors under the private sectorial category. While the formal sector and subsector encompass SMEs registered by government's business Commission for Value Added Tax (VAT), the informal sector or subsector comprises even more businesses recognised as micro-enterprises and relatively small businesses that operate mainly informally, therefore may not be duly registered and probably exempted from taxes. In their pre-lockdown survey conducted in March 2020, McKinsey and Co. (2020:3) estimate that as much as $80 \%$ of their "respondents" were already contemplating cutting down on their "spending across all retail categories", perhaps due to growing cynicism throughout the lockdown. They also established more $+70 \%$ of consumers who envisage similar cuts on their services-related expenditures. Undoubtedly, these foreseeable spending cuts came with enormous costs on the businesses shortly affected, but those were by far non-comparable to the actual lockdown-instigated restrictions whose implications reflected on certain aspects critical to businesses. They include their gross revenues, labour force, resources' inflow and outflow of the businesses and the pricing of their existing goods and services.

Table 2. Operational capacities of business by turnover during COVID-19 lockdown

\begin{tabular}{llllllll}
\hline $\begin{array}{l}\text { Annual turnover } \\
\text { range }\end{array}$ & $\begin{array}{l}\text { Continuing } \\
\text { trade at } \\
\text { capacity }\end{array}$ & $\begin{array}{r}\text { to } \\
\text { full }\end{array}$ & $\begin{array}{l}\text { Continuing to } \\
\text { trade partially }\end{array}$ & $\begin{array}{l}\text { Permanently } \\
\text { ceased trading }\end{array}$ & $\begin{array}{l}\text { Temporarily } \\
\text { closed or paused } \\
\text { trading }\end{array}$ & Not sure & Total \\
\hline R0-R2 million & 27 & 80 & 14 & 74 & 1 & $\mathbf{1 9 6}$ \\
\hline $\begin{array}{l}\text { R2 million - R30 } \\
\text { million }\end{array}$ & 55 & 164 & 8 & 93 & 1 & $\mathbf{3 2 1}$ \\
\hline $\begin{array}{l}\text { R30 million - } 36 \\
\text { R80 million }\end{array}$ & 91 & 0 & 17 & 0 & $\mathbf{1 4 4}$ \\
\hline $\begin{array}{l}\text { R80 million - } 64 \\
\text { R300 million }\end{array}$ & 94 & 1 & 19 & 0 & $\mathbf{1 7 8}$ \\
\hline $\begin{array}{l}\text { R300 million - }-18 \\
\text { R500 million }\end{array}$ & 45 & 0 & 4 & 0 & $\mathbf{6 7}$ \\
\hline
\end{tabular}




\begin{tabular}{lllllll}
\hline $\begin{array}{l}\text { R500 million } \\
\text { R1 billion }\end{array}$ & -31 & 35 & 1 & 5 & 0 & $\mathbf{7 2}$ \\
\hline$>$ R1 billion & 48 & 44 & 0 & 5 & 0 & $\mathbf{9 7}$ \\
\hline Not sure & 0 & 1 & 0 & 0 & $\mathbf{4}$ \\
\hline Total & $\mathbf{2 7 9}$ & $\mathbf{5 5 4}$ & $\mathbf{2 4}$ & $\mathbf{2 1 7}$ & $\mathbf{5}$ & $\mathbf{1 0 7 9}$ \\
\hline
\end{tabular}

Source: Stats SA (2020a:4)

\subsection{Implications on Gross Revenues of Businesses}

As the lockdown began at alert Level 5 across South Africa, one key aspect that displayed significant effect was the gross revenues of many businesses in the country. These businesses, which were then classified under a nonessential category owing to their operative relevance to emergency healthcare for COVID treatment, witnessed a sharp decline in returns because lockdown restrictions limited their operation to a reasonable extent. Throughout April, while lockdown alert level intensified at Level 5, a remarkable proportion of these businesses reported that their "turnover was below the normal range" (Stats SA, 2020a:3). A breakdown of the statistical evidence from the national databank reveals the magnitude of this decline, as displayed in Figure 4. As early as mid-April when Statistics SA conducted the first survey with $85.4 \%$ of the 1079 businesses, which participated in the national survey, reported this abnormal decline in their gross revenue. The second survey, however, recorded a higher increase to $89.6 \%$ as at the end of April the same year. Most affected businesses were in the manufacturing and trade $(20.9 \%$ and $17.1 \%$ respectively), with agriculture, hunting, forestry, and fishing businesses trailing closely at 16.4 , while real estate and related business services were separated by $11.7 \%$ from businesses categorised under community, social and personal services and those in transport, storage and communication (Table 1)(Stats SA, 2020a).

Other businesses which reported similar shortfall in their gross revenue were those in construction (5.7\%), mining and quarrying (2.5\%), and a host of 41 other businesses, which tallied up to $3.8 \%$ of the total "respondents" by their industrial classifications. The implication of these abnormal declines in revenue could equal as much as tens and hundreds of millions and even billions of Rands, as represented in their "annual turnover range" (Figure 3). For instance, from the 24 businesses which "permanently ceased trading" during the period under review, 14 were within a turnover range of up to R2 million, eight of those businesses have turnovers of up to R30 million, while one apiece fell within a turnover range of R300 million and R1 billion, respectively. Those are comparable to a whopping 554 businesses, which continued to "trade partially" within turnover ranges of up R2 million and over R1 billion, and 217 other businesses which "temporary closed or partially paused trading" with similar turnover range. Conversely, meagre percentages $(1.3 \%, 1.1 \%$ and $1.5 \%$ respectively) of businesses surveyed during the period indicated a relative increase in their turnover during the three periods of the national survey. This is probably due to of a higher demand for the goods and services of those few businesses, which continued to operate under "essential services" category. While other businesses, attempting to maintain their gross revenue over the same period, were only a small proportion accounting for $13.3 \%, 9.3 \%$ and $14.3 \%$ respectively, as represented in the statistical evidence (Figure 4)(Stats SA, 2020a).

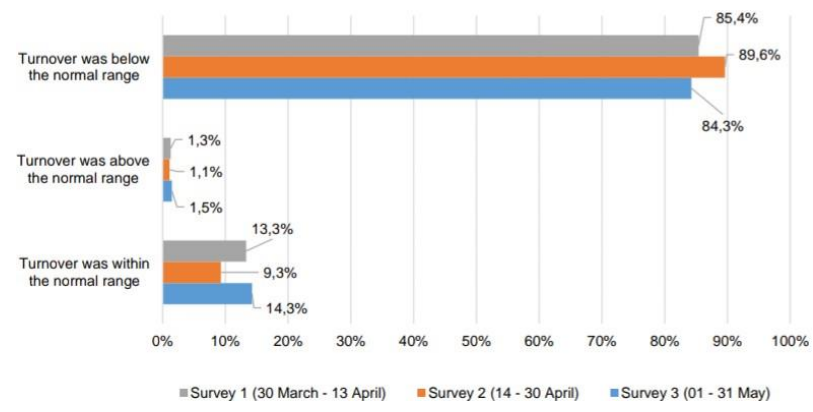

Figure 3. Effects of COVID-19 lockdown on businesses' gross revenues in South Africa

Source: Stats SA (2020a:3) 
As the continent's most affected country with coronavirus, South African business's effect from the pandemic is not incongruent from other countries globally. In the United States, for instance, ill-reputed as the world's most affected country lately, Fairlie (2020:3) reports that several "high-revenue" businesses, which were also surveyed in the same month of May, attest to a similar rate of decline in their gross revenue with " $86 \%$ [reporting] immediate negative effects" because of operational stoppage and even "closure from the pandemic". Fairlie observes that:

"although there was no way to know if these business closures will be permanent, they certainly influence the revenues and profit levels, employees, and take home (sic) earnings from these businesses” (Fairlie, 2020:2).

\subsection{Implications on the Employees of Businesses}

The coronavirus pandemic brought massive crippling effects on South African businesses owing to their deteriorating revenue or turnover, but those are least comparable to the untold consequences it caused on the workers who direly depended on the incomes by their employment. The onset of lockdown alert Level 5 in South Africa regrettably led to the closures of many of these businesses, translating into the temporal cessation of work for the affected workers. Most of these employees are economically anchored by the private business sector whose employment generation capacity is far higher in the national economy (McKinsey \& Co. 2020:3). The implication is that the possible redundancy from these businesses' closures affected a higher percentage of workers, and by extension, their close relatives who directly or indirectly depended on their regular income. Jain et al. (2020:16) estimate that $33 \%$ of the newly affected workers fell "below reasonable poverty thresholds" just within a stretch up till April 2020, representing "an additional one million to 1.7 million individuals" whose means of economic livelihood went down the drain. They fear a more ripple effect that could cause more sufferings to members of the public as the poverty flares to the dependents of the jobless worker:

"Workers typically support many dependants who will also be affected by a worker losing her job. .... Thus, for our estimate of COVID-19-related job loss pushing 1 to 1.7 million job-losers into poverty, we conjecture a broader job-loss effect of approximately 3 million to 5.5 million individuals falling into poverty, when accounting for the dependents of job-losers" (Jain et al., 2020:17).

The situation in South Africa is not an isolated case when compared to other countries globally. At the world stage, latest estimates from the International Labour Organisation's Global Summit on the pandemic, indicate a significant detrimental effect of the pandemic on the global workforce. The world's largest virtual collection of employers and employees, and governments - which took place at the beginning of the third quarter of 2020 under the theme "COVID-19 and the world of work: building a better future of work" - focused on "how to address the economic and social impacts of the pandemic", and established that coronavirus pandemic "has devastated the world of work, causing massive human suffering and laying bare the extreme vulnerability of many millions of workers and enterprises" (ILO, 2020:2). According to awful reports in their communiqué:

"The large scale (sic) workplace closures around the world in response to COVID-19 have led to a reduction in hours worked of 10.7 per cent worldwide in the second quarter of this year. That translates into the loss of 305 million jobs - calculated on the basis of a 48 hour (sic) working week. .... Its future trajectory remains uncertain. .... But in its world of work affect it has hit the most disadvantaged and vulnerable in the hardest and cruellest way, so exposing the devastating consequences of inequalities" (ILO, 2020:2).

More reports from the Summit further reveal that the devastating effect of the pandemic is most felt within the informal sector of the global economies, where many micro and small-scale businesses support most of the populace in different countries across the globe. They reveal that the consequence of the sector's average revenue shrinking "by 60\%" resulted in abrupt redundancy for more than "six out of ten working people [who] make their living from day to day", which translates to 1.6 billion out of two billion workers globally who now "face an imminent threat to their livelihoods" (ILO, 2020:2). This includes "a drastic increase in poverty" (ILO, 2020:2) and the danger of "an additional 200 million ... expected to lose access to basic food and nutrition in the months ahead" according to warnings by the World Food Programme (WFP, 2020:4):

"Enterprises, particularly micro, small, and medium-sized ones with few reserves to tide them over even short periods of inactivity face great uncertainty, if not worse. In the four sectors hardest hit by the pandemic alonewholesale and retail trade and vehicle repair; manufacturing; accommodation and food services; and real estate and business and administrative activities - no less than 436 million enterprises are at high risk of serious disruption" (ILO, 2020:2).

Most businesses equally affected by the pandemic in South Africa, also fall into the above four sectors by their industrial categorisation. According to Statistics SA (2020a:1), trade, manufacturing, real estate and other business 
services, and community, social and personal services amount to over $60 \%$ of entire "responding businesses by industry" which participated in the month-long survey. More evidence from the statistical business impact survey of May 2020 further suggest that $35.1 \%$ of the entire businesses had to adopt desperate measures, such as decreasing their business working hours. The employees of $25.8 \%$ of affected businesses paid the ultimate economic sacrifice with layoffs "in the short term" (Figure 5).

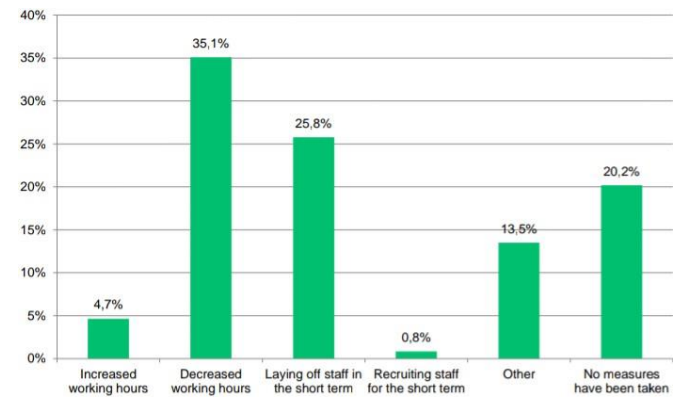

Figure 4. Impact of COVID-19 lockdown on the business's workforce

Source: Stats SA (2020a:8)

Khambule (2020:100) observes that since many people in South African rely on income from this sector of the economy, its declassification from "essential services created a bleak future for those active in this sector of the economy". Whereas the country still reels with over half the infection rates within the continent, "slow growth and macroeconomic imbalances before COVID-19 and the application of strict lockdown measures ... will translate into a severe recession which will have negative consequences concerning employment and already elevated poverty and inequality levels" (United Nations Conference on Trade and Development, 2020:30). The obvious outcome concerning delayed income, pay cuts and even non-payments during the affected periods of redundancies, would have transcended into woeful socioeconomic difficulties for not just the people employed by these businesses but also many others who depend on them.

\subsection{Implications on Goods and Services' Inflow and Outflow Within and Outside the Country}

The period, May 2020, under review also recorded the height of travel restrictions both within and outside South Africa, in a bid "to contain the spread of the virus ... from ... countries that have high infection rates" of the COVID-19 pandemic (Ramaphosa, 2020). These restrictions, however, spelt doom for businesses which depended on global transportation networks - on air, land and sea - for the sourcing of their valued raw material and distributing their finished goods and services. Data from Statistics SA (2020a), therefore, reveal that a significant proportion of these businesses (as much as 40\%) reported a negative effect of the pandemic on their material goods and services' inflow into South Africa, with a virtual corresponding negative effect on exports as reported by over $30 \%$ of businesses in the same period (Figures 5 and 6).

Aside from the mechanism of transportation networks bearing more brunt since the affected trading partner-countries observed strict travel restrictions and foreign exchange in currencies also came to limelight, with the United Nations Conference on Trade and Development (UNCTAD) reporting that the "South African Rand" was second of three "hardest-hit currencies" as at mid-2020 (UNCTAD, 2020:25). The implication is that even where imports and exports are permitted on grounds of "essential" goods or services classification, the higher foreign exchange rate would jeopardise any projected returns for businesses that swim against the pandemic tide. 


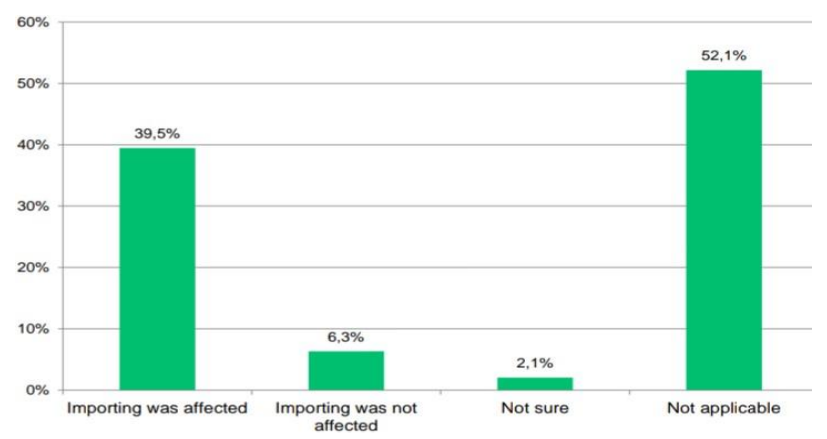

Figure 5. Effect of COVID-19 lockdown on inflows and outflows of Businesses' goods/services (importing) Source: Stats SA (2020a:10)

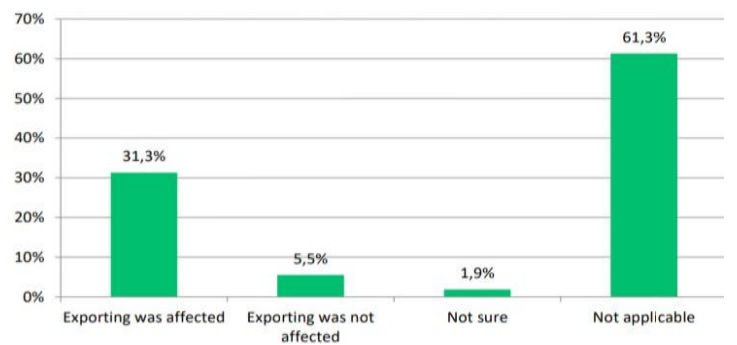

Figure 6. Effect of COVID-19 lockdown on inflows and outflows of Businesses' goods/services (exporting) Source: Stats SA (2020a:10)

In their analyses of "essential" trade flows that relate to the health sector of countries which make up the British Commonwealth, Gopalakrishnan et al. (2020:5) contend for instance that the travel restrictions imposed by "notable Commonwealth countries [including South Africa]", caused unpredictable magnitude of brutality to not just the (health) sectorial capacity in containing the pandemic but also the national economy of each member countries. Their major concern is that certain industries which had a longstanding tradition of "offshoring and outsourcing" raw material and other unfinished and finished products outside their national borders, suffered greatly because of increasing difficulties in the supply chain for those essential products and services. Sequences of unfortunate incidents abound, such as:

"Production stoppages in the primary sources of the supply chain, shortages of raw materials, sub-assemblies and paralysed transport networks, [which] have all disrupted the production and supply of [these] essential commodities... [leading to] a future that is uncertain and disorganisation in the execution of activities, [and] ensuing ... wild spread of COVID-19" (Gopalakrishnan et al., 2020:5).

Gopalakrishnan et al. (2020:8) attribute the hitherto absence of "standard medicines or treatment procedures for the virus as the foundation for the umpteenth "demand for diagnostic kits, critical medicines, artificial respiratory equipment and services". To this effect, Commonwealth member nations adopted frantic policy measures, such as tariff concessions and non-tariff restrictions (Gopalakrishnan et al., 2020:18-24). These was implemented to avoid a dire shortage of vital medical supplies, with South Africa leading in implementing "import tariff reduction" in Africa, on grounds that such imports are "essential services" as gazetted in government's Disaster Management Regulations No. 43148 of 27 March 2020 (Gopalakrishnan et al. 2020:23).

Soon after, other countries in Africa adopted similar policies to balance their goods and services inflow and outflow to evade possible scarcity crisis. Agarwal and Chonzi (2020:4), for instance, observe that many African countries have actually "implemented inward-looking measures to protect their domestic markets" due to many uncertainties that trial the invisible pandemic enemy. Such measures, according to them, include "export bans, import restrictions and subsidies to import-substituting industries", aimed at reducing their "dependence on imported goods" to "improve self-reliance". As oddly as this may appear, especially at such unusually tragic period, Agarwal and Chonzi (2020:4) warn that such: 
"Restrictive" measures will most likely be disastrous for many African countries whose local manufacturing capacities are in jeopardy, as this can trigger health and food crises in the continent. Therefore, the extant border-closure measures could also come with dire consequences that affect the movement of "essential commodities" into those places that are most affected by the pandemic which means more people will be deprived of "the much-needed health care and food supplies" (Agarwal and Chonzi, 2020:4).

On the long run, Agarwal and Chonzi (2020:9) observe the high dependency rate of African industries on both Western and Eastern powers with over half of the continent's machinery and transport equipment needs coming from "Europe, China and India [at 35\%, 16\% and 14\% rates, respectively]" while fearing that more restrictions on international trades could have a disastrous effect on the volume of goods and services within the economies, as this can equally affect the costs of those goods owing to changes in demand.

\subsection{The Pricing Factors}

By the lockdown's effect on normal business operations in South Africa, which then brought a significant negative effect on the goods and services with the gross outputs and earnings of many businesses, the price of most commodities would likely remain the same in the market. Evidence from the national statistical body in South Africa, therefore, indicates that nearly $40 \%$ of businesses surveyed in the period under review reported that prices of goods and services "increased more than normal", as they still reeled from the effect of COVID-19 lockdown (Stats SA, 2020a:11). More reports from 12.4\% (Figure 7) of the businesses surveyed further reveal varied effects on various commodities which made "some prices increased more than normal [while] prices decreased more than normal" (Stats SA, 2020a:11). However, $22.8 \%$ of other businesses attest to that the price of their commodities "did not change more than normal"; with just $1 \%$ of the businesses (about 11 businesses under survey) indicating that prices of their goods and/or services went even higher. The remainders of the businesses, which make up to $25 \%$, displayed signs of uncertainty regarding price change on their commodities, but the change was not necessarily applicable to the rest.

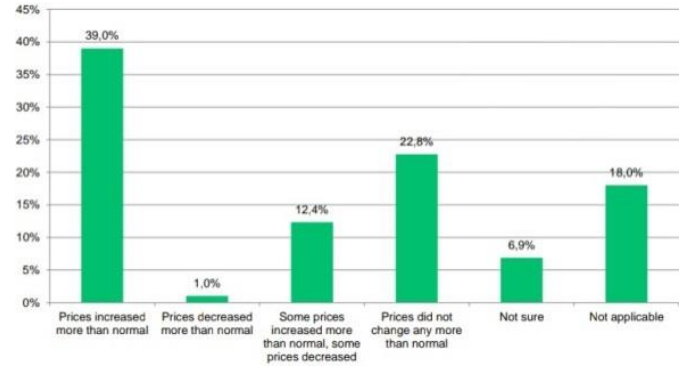

Figure 7. Effects of COVID-19 lockdown on prices of Business' supplies

Source: Stats SA (2020a:11)

A comparative check of a similar effect of COVID-19 pandemic on commodity prices in other Sub-Sahara African economies, however, reveals a different report in toto. Kassa (2020:1-2), for instance, admits that although the pandemic has "a severe economic impact" on Sub-Sahara economies' trade, it leaves many with a rather free fall of commodity prices in the markets. Kassa (2020:2) attributes this free fall to the overdependence of the region's economies on certain commodities whose inflow was hampered during the lockdown. With no local alternatives in these economies relatively constricted below the Sahara region, "almost all commodity prices saw sharp declines", which then exposed the "economic vulnerabilities" of these countries "due to a lack of diversification" (Kassa, 2020:3a). As each economy is bereft of virtually any valued input to add in the global value chain, Kassa (2020:3b) regrets that export volume within the region might keep depreciating "due to shortage of intermediate inputs". This, he says, comes from the following:

"with more adverse consequence on economies like South Africa, Kenya, Ethiopia and others which - though well-integrated or still transitioning in the global value chain - "will be affected the most" (Kassa, 2020:3b).

Agarwal and Chonzi (2020:8), conversely, contend about a possible worst-case scenario within the region's developing economies. They infer that the pandemic-induced restrictions that affect trade volumes and each country's contribution to the global value chain would most likely be negatively consequential with spiked 
commodity prices as already reported by most businesses in South Africa. Conceding to that export restrictions lead to price rise, Agarwal and Chonzi (2020:10) posit that the effect of the pandemic on individual economies in the continent is most likely to be worse on "commodity exporters" like Ghana, Algeria, Nigeria, Angola and Congo. This is "due to reduced demand that has resulted in price declines and exchange rate instabilities". For a leeway, Agarwal and Chonzi (2020:8-9) suggest the steady easing of most trade restrictions on grounds that historical economic achievements within the continent had always been by trade liberalisation while envisaging the hope of recovery and growth for emerging economies the extreme consequences of the pandemic over most foreseeable future.

\section{Private Business Sectors in a Rebuilding and Recovering Economy}

Anon to the 15 October 2020 October new economic recovery plan as the announcement by President Cyril Ramaphosa, South Africans may, at last, have caused to breathe afresh with remainders of their lives and livelihoods in the post-pandemic era. The much anticipated and purportedly "richly consulted" recovery plan, is believed to provide an average South African (and the country) a new lease of life regarding decent socioeconomic cum physical wellbeing, indispensable for any meaningful development to occur in the country. The 38-page document at a national parliament's hybrid session as "The South African Economic Reconstruction and Recovery Plan", is devised to restore the pandemic-stricken economy - not just to its pre-pandemic state - but to "forge a new economy in a new global reality" (RSA, 2020:3). It is organised into three phases, indicating, "engage and preserve" which encompasses the health and wellbeing of all South Africans, "recovery and reform", which ensures the steady recovery of the economy amidst the pandemic uncertainties, and the "reconstruct and transform" phase focusing on "building a sustainable, resilient and inclusive economy" (RSA, 2020:3).

According to government's top implementation strategy which will hopefully facilitate the reconstruction and recovery process of South Africa and its economy, emphases will be placed on apposite "regulatory changes" through which government intends creating an enabling environment that will "ease" the process of "doing business" in the country (RSA, 2020:4). The government intends to implement "structural reforms" in the private business sector by dropping entry barriers for aspiring business investors, to "make it easier for businesses to start, grow, and compete" (RSA, 2020:4) in the newly reconstructed and recovering economy.

A sectorial preview of the entire implementation process further indicates that the agricultural business subsector, for instance, will receive "over R80 billion in ... production value" that might create "317 000 new jobs" to support many households from any food insecurity challenges soon (RSA, 2020:23). The financial sector is also expected to support continuous credit flow "to households and businesses" through proper deregulations (RSA, 2020:25) while SMMEs will enjoy "supportive ecosystem" with government's renewed support for both the "formal and informal SMMEs" subsectors to enjoy the ease of doing business in South Africa (RSA, 2020:34). In observation of the enamours potential for growth and development of the economy as presented in the new economic recovery plan, the dawn of a new era for South African private business sector may be right at hand.

\section{Concluding Remarks}

South Africa's formal business sector, and the economy barely witnessed the contraction since the 26 years history of the democratic dispensation - no thanks to the novel coronavirus pandemic. As a major key-payer and driver of the hitherto most advancing economy in Africa, the business sector in South Africa was contributory to over half of the national employment generation in the country. This implies more efforts gearing towards its earliest recovery, since the recovery of the sector could trigger rapid growth and revival in other sectors, translating into the full recovery of the entire economy forthwith. With a rare economic recovery opportunity insight, most unlikely for many economies within the continent, South Africa can braise the trial and regain its glory as of the continental leading economy - but this only depends on how the nation's economic burden bearer (the private business sector) is predisposed. And if the popular adage that the ox which treads the corn should never be muzzled is anything to go by, then the private business sector of the economy should take pre-eminence in this "recovery process", the hope of economical means of livelihood for millions of ordinary South Africans.

The foregoing remarkably portrays a glimpse of the devastating effect of the COVID-19 pandemic on South Africa's private business sector. From mining, manufacturing, and construction, to agricultural, transport, real estate and trade - with a host of other businesses in construction, social and personal services, electricity and many others, the pandemic's negative implications are observable on the businesses' turnover, their workforce, their goods and services in/outflows and their pricing scale. Construed from a special countrywide survey conducted in the heat of the pandemic lockdown under the auspices of the national statistical body and the administrative commission responsible for the formal business sector, the evidence in this affect assessment exemplifies first-hand perceptions 
of businesses whose annual turnover range rises above one billion in South African Rand and includes down to two million or fewer.

Their huge financial base alone clearly depicts their relevant socioeconomic support to the economy, since they manage most of the nation's employment generations and corporate social compacts within host communities. The chronicle of the negative effects of the pandemic on the formal business sector is so significant because it also reflects the situation of many South Africans whose means of economic livelihood are anchored within the sector, although no detailed situational review of employees of these businesses is provided. With just over a thousand businesses reporting during the month-long survey in May, there is a concern of incommensurate data, considering the bulk of existing businesses whose data are not available to the national statistical agency in the period under review. Otherwise, the above evidence of COVID-19 lockdown's effect on South Africa's formal businesses attest to the sad reality that besides the enamours carnage caused by the pandemic with losing lives of South Africans, there are more fears that many livelihoods might still make the ultimate sacrifice should concrete rescue cannot reach them on time or not reach them at all.

\section{References}

Agarwal, P., \& Chonzi, M. (2020). Impact of COVID-19 on international trade: Lessons for African LDCs.

Bakari, S. (2017). The impact of domestic investment on economic growth: New evidence from Malaysia. Munich: Munich Personal RePEc Archive. Retrieved https://mpra.ub.uni-muenchen.de/79436/1/MPRA_paper_79436.pdf

Bono, L. (2020). Collaboration critical for rebuilding SA's economy post COVID-19: opinion. Without Prejudice, 20(6), 59-59.

De Villiers, C., Cerbone, D., \& Van Zijl, W. (2020). The South African government's response to COVID-19. Journal of Public Budgeting, Accounting \& Financial Management, 1096-3367. https://doi.org/10.1108/JPBAFM-07-2020-0120

Ede, C. I. (2017). An assessment of government's national youth policies' impact on entrepreneurship development of unemployed youths at grassroots level in Empangeni. Master's Dissertation, Department of Public Administration, University of Zululand.

Fairlie, R. W. (2020). The impact of COVID-19 on small business owners: Continued losses and the partial rebound in May 2020 (No. w27462). National Bureau of Economic Research.

Gopalakrishnan, B. N., Vickers, B., \& Ali, S. (2020). Analysing the effects of the COVID-19 pandemic on medical supply chains in commonwealth countries. https://doi.org/10.14217/24133175

ILO. (2020). COVID-19 and the world of work: building a better future of work. Genève: International Labour Organisation.

Jain, R., Budlender, J., Zizzamia, R., \& Bassier, I. (2020). The labor market and poverty impacts of covid-19 in South Africa. Cape Town: SALDRU, UCT. SALDRU, Working Paper No. 264. Retrieved from http://hdl.handle.net/11090/980

Kanu, I. A. (2020). COVID-19 and the economy: an African perspective. Journal of African Studies and Sustainable Development, 3(2), 29-36.

Kassa, W. (2020). COVID-19 and Trade in SSA: Impacts and Policy Response. Africa Knowledge in time World Bank Policy Brief, 1(1), 1-8. https://doi.org/10.1596/33841

Khambule, I. (2020). The effects of COVID-19 on the South African informal economy: limits and pitfalls of government's response. Loyola Journal of Social Sciences, 34(1), 95-109.

McKinsey, C. (2020). How South African SMEs can survive and thrive post COVID-19. New York: McKinsey \& Company publications.

NICD. (2020). An update on the novel coronavirus disease 2019 (COVID-19) outbreak, South Africa. Pretoria: The National Institute for Communicable Diseases, South Africa.

Ramaphosa. (2020). Statement by President Cyril Ramaphosa on progress in the national effort to contain the COVID-19 pandemic. 16 September 2020 by SA COVID-19 Online Resource \& News Portal. Retrieved October

11 , 
https://sacoronavirus.co.za/2020/09/16/statement-by-president-cyril-ramaphosa-on-progress-in-the-national-effo rt-to-contain-the-covid-19-pandemic-3/

Roux, A. (2016). Everyone's Guide to the South African Economy 12th edition. Penguin Random House South Africa.

RSA. (2020). The South African economic reconstruction and recovery plan. Pretoria: Government of South Africa.

Smulders, S., Sitglingh, M., Franzen, R., \& Fletcher, L. (2012). Tax compliance costs for the small business sector in South Africa: Establishing a baseline. eJTR, 10, 184.

Stats, S. A. (2020a). Business impact survey of the Covid-19 pandemic in South Africa. Pretoria: Statistics South Africa.

Stats, S. A. (2020b). Gross domestic product: Second Quarter 2020. Statistical Release P0441. Pretoria: Statistics South Africa.

Stats, S. A. (2020c). The South African Economy shrinks by 0.7\%. Retrieved October 7, 2020, from http://www.statssa.gov.za/?p=9989

Swilling, M., Musango, J. K., \& Wakeford, J. (2016). Greening the South African Economy: Scoping the issues, challenges and opportunities. Juta and Company (Pty) Ltd.

UNCTAD. (2020). Trade and development reports 2020: From global pandemic to prosperity for all: Avoiding another lost decade. Geneva: The United Nations.

WFP. (2020). Responding to the development emergency caused by COVID-19: WFP's medium-term programme framework. Rome: The World Food Programme.

\section{Copyrights}

Copyright for this article is retained by the author(s), with first publication rights granted to the journal.

This is an open-access article distributed under the terms and conditions of the Creative Commons Attribution license (http://creativecommons.org/licenses/by/4.0/). 